\section{Apolipoprotein E polymorphism and functional disability in Brazilian elders: the Bambuí Health and Aging Study}

\author{
Polimorfismo da apolipoproteína E e incapacidade \\ funcional em idosos brasileiros: Projeto Bambuí
}

\author{
Polimorfismo de la apolipoproteína E e \\ incapacidad funcional en los ancianos \\ brasileños: Proyecto Bambuí
}

\begin{abstract}
Numerous studies have associated the apolipoprotein E (apoE) \&4 allele with worse health status, but few have assessed the existence of genotypedependent variations in functional performance. Among participants in the Bambuí Health and Aging Study, Minas Gerais State, Brazil, 1,408 elderly underwent apoE genotyping. Functionality was assessed with a questionnaire, and individuals were classified as dependent in basic activities of daily living (BADLs), instrumental activities of daily living (IADLs), and mobility. The association between apoE genotype and functional status was assessed by logistic regression, taking confounding factors into account. Presence of $\varepsilon 4$ allele was associated with lower odds of mobility deficit (OR $=0.65 ; 95 \% C I$ : 0.47-0.92) in the adjusted analysis. There were no significant differences in relation to presence of dependency in BADLs and IADLs. The reasons are not entirely understood, but they may involve the role of 44 allele as a "thrifty gene" in a sample exposed to high risk of infectious and nutritional diseases in the past.
\end{abstract}

Apolipoprotein E4; Disabled Persons; Aged
Rodrigo Zunzarren Megale 1,2 Antônio Ignácio de Loyola Filho 3,4 Josélia Oliveira Araújo Firmo ${ }^{3}$ Maria Fernanda Lima-Costa 3 Sérgio Viana Peixoto 3,4

\author{
${ }^{1}$ Fundação Hospitalar do \\ Estado de Minas Gerais, Belo \\ Horizonte, Brasil. \\ 2 Hospital da Polícia Militar \\ de Minas Gerais, Belo \\ Horizonte, Brasil. \\ 3 Centro de Pesquisas René \\ Rachou, Fundação Oswaldo \\ Cruz, Belo Horizonte, Brasil. \\ ${ }^{4}$ Escola de Enfermagem, \\ Universidade Federal de \\ Minas Gerais, Belo Horizonte, \\ Brasil.
}

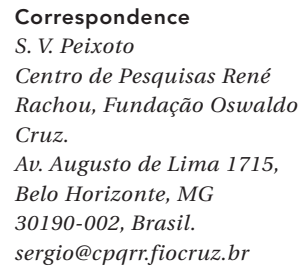




\section{Introduction}

The apolipoprotein E (apoE) gene has been extensively studied as an aging-related gene. Beyond its role in lipid metabolism, apoE is associated with atherosclerosis, neuronal repair and maintenance, inflammation and, possibly, immune response to infectious diseases 1 . Several studies have shown an association between the $\varepsilon 4$ allele (rs429358) and age-related diseases such as coronary heart disease $2,3,4$, stroke 5 and Alzheimer's disease 6,7 . The effect of this genotype in mortality has also been widely investigated, but the results are not consistent across all populations 8,9,10,11.

Researches have suggested that the apoE gene should be considered a "frailty gene" that increases the age-specific susceptibility to death 12 . If the apoE gene really is a "frailty gene", it would be reasonable to expect $\varepsilon 4$ carriers to accumulate more age-related diseases and to demonstrate poor functional performance in advanced ages 13,14. A small number of studies have addressed genotype-dependent variations on functional performance of the elderly and have reported conflicting results. In some populations, no significant association between the apoE genotype and functional decline has been detected 15,16, while in other cases, the $\varepsilon 4$ allele was associated with worse functional status among men only 17 or among women only 18 . Two previous studies related the presence of $\varepsilon 4$ allele to poor functional performance 19,20, but the same allele was considered a protection factor against activities of daily living impairments among elderly Americans 14. Impairments in instrumental activities of daily living functional performance were more prevailent in elderly men carrying $\varepsilon 2$ allele (rs7412) in just one sample ${ }^{21}$.

Although different studies present a variation in the approach to assessing functional status, the results have shown a strong discordance with regard to the association between functional status and the apoE genotype among the aged. It is also important to point out that most of these studies were conducted in Europe and North America, with just one study conducted in Taiwan 15.

The present study aims to evaluate the association between the apoE genotype and functional status, considering performance in instrumental activities of daily living (IADL), basic activities of daily living (BADL) and mobility-related tasks, in an aged and low-educated population in Brazil.

\section{Methods}

\section{Sampling study}

The Bambui Health and Aging Study has been carried out since 1997 in Bambuí, a city of 15,000 inhabitants located in Minas Gerais State (Southeastern Brazil). The leading causes of death among elderly residents in Bambuí are stroke, Chagas disease and coronary heart disease. Bambuí has been an endemic area for Chagas disease - a parasitic disease caused by the protozoan parasite Trypanosoma cruzi, and the rate of T. cruzi infection is still high among elderly residents due to a cohort effect 22,23.

The cohort baseline survey was conducted in 1997 and the study population was identified by full census report in the city. All residents aged 60 or older $(1,742)$ were invited to join the study; 1,606 were interviewed (92.2\%) and 1,496 $(85.9 \%)$ were submitted to physical examinations and had blood samples collected. Details on the methodology and participants' health profile in the baseline are available in previous papers 22,23.

The original study proposal of the Bambui Health and Aging Study was approved by the Ethics Research Committee at Oswaldo Cruz Foundation (Fiocruz) in Rio de Janeiro with an informed consent form signed by the participants at baseline and at each subsequent visit.

\section{Functional measurements}

Functional disability was assessed regarding selfreported performance on basic activities of daily living (BADL), instrumental activities of daily living (IADL), and mobility-related tasks 24,25,26. The participants were asked whether they experienced any difficulties in any of the following BADL: bathing, dressing, getting in and out of bed and feeding. Questions about being able to manage money, do household chores and prepare food on their own were also asked in order to assess IADL performance. The mobility-related questions concerned any difficulties in walking 100 yards, climbing stairs, stooping, squatting and kneeling, lifting and carrying weights, walking across a room, getting up from a chair and walking without assistance. The candidates who reported being unable to perform at least one of the tasks without help for each domain were considered disable in BADL, IADL or mobility.

DNA extraction, PCR amplification and RFLP genotyping

Genomic DNA was obtained from the blood samples using the Wizard genomic DNA extraction 
kit (Promega, Madison, USA) and were subjected to the polymerase chain reaction amplification, using the following primers: forward 5' TAA GCT TGG CAC GGC TGT CCA AGG A 3' and reverse 5' ACA GAA TTC GCC CCG GCC TGG TAC AC 3'. The amplified DNA was subjected to the restriction fragment length polymorphism (RFLP) technique, with digestion by HhaI, reproducing the following patterns: $\varepsilon 2 \varepsilon 2,83$ and $91 \mathrm{bp}$; $\varepsilon 3 \varepsilon 3,91,48$, and $35 \mathrm{bp}$, and $\varepsilon 4 \varepsilon 4,72,48,35$, and $19 \mathrm{bp} 27$. These fragments were visualized on $4 \%$ agarose gels.

\section{Confounders}

Sociodemographic factors such as age, gender, skin color and schooling had been considered potential confounding factors and were used as adjustment variables, as well as smoking status, mini-mental scores, hypertension, diabetes, coronary heart disease, stroke, LDL and HDL cholesterol levels and C-reactive protein (CRP) levels.

Schooling was assessed by numbers of completed years of education ( 0 to 3 years and 4 years or more). Skin color grading was based on the different skin color that individuals displayed in photographs. This variable was dichotomized into white and non-white for the study analysis. Individuals who had smoked at least 100 cigarettes in their lifetime and were still smoking were considered current smokers.

Cognitive functioning was assessed using a Portuguese version of the Mini-Mental State Examination (MMSE). The cut-off used in this population was 22, as defined in an earlier publication 28. Stroke 29 and coronary heart disease 30 were assessed by means of standardized questionnaires.

Standard desk mercurial sphygmomanometers (Tyco's 5097-30, USA) and stethoscopes (Littman's Cardiology II, USA) were used for measuring blood pressure. Blood pressure was measured 30 or more minutes after the last caffeine intake or cigarette smoked. Three measures were taken after 5 minutes of initial rest and subsequently at 2-minute intervals. Hypertension was defined by mean systolic blood pressure $>140 \mathrm{mmHg}$ and/ or mean diastolic blood pressure $>90 \mathrm{mmHg}$ and/or current use of hypertension medication.

Biochemical analyses (fasting glucose, HDL cholesterol, LDL cholesterol and triglyceride) were determined with standardized enzymatic methods, using automated equipment (Eclipse Vitalab; Merck, Netherlands). Diabetes mellitus was defined as a fasting blood glucose level equal to or higher than $126 \mathrm{mg} / \mathrm{dL}$ and/or current use of hypoglycemic medication. Highly sensitive Creactive protein levels were determined using the immunonephelometric method (High Sensitive CRP, Dade Behring, Germany).

All interviews were conducted in the participants' homes by trained and certified interviewers, and were answered by the participant or, if they suffered from a life-limiting condition, by a close relative. Blood collection and examinations were performed at the clinic. More details can be found in previous publications 23 .

\section{Data analysis}

Descriptive analyses of all variables were performed using absolute frequency, relative frequency, mean, standard-deviation, median and 25th and 75th percentiles for the total population and for each genotypic group.

Considering all the possible apoE genotypes ( $\varepsilon 2 \varepsilon 2, \varepsilon 3 \varepsilon 3, \varepsilon 4 \varepsilon 4, \varepsilon 2 \varepsilon 3, \varepsilon 2 \varepsilon 4$ e $\varepsilon 3 \varepsilon 4)$, individuals were classified in three groups: i) $\varepsilon 3$ carriers ( $\varepsilon 3 \varepsilon 3)$; ii) $\varepsilon 2$ carriers $(\varepsilon 2 \varepsilon 2, \varepsilon 2 \varepsilon 3)$ and iii) $\varepsilon 4$ carriers $(\varepsilon 4 \varepsilon 4, \varepsilon 4 \varepsilon 3)$. In all analyses, the homozygous genotype ( $\varepsilon 3 \varepsilon 3)$ was considered the reference group. Furthermore, the participants were classified as $\varepsilon 4$ carriers or non- $\varepsilon 4$ carriers. Individuals with the $\varepsilon 2 \varepsilon 4$ genotype $(1,4 \%)$ were excluded from all analyses because of the opposing effects of these two alleles on health status 31 .

Association between self-reported functional disability and the apoE genotypes (or the presence of an apoE $\varepsilon 4$ allele) were measured using logistic regression. Odds ratio (OR) and 95\% confidence intervals $(95 \% \mathrm{CI})$ were calculated for each domain (BADL, IADL and mobility). The analysis was adjusted for potential confounding factors. The Hosmer-Lemeshow test and residual plots were used to evaluate if the model was suitable.

The statistical analysis was performed by means of version 13.0 of the Stata software (StataCorp LP, College Station, USA) and a significance level of 0.05 was considered.

\section{Results}

Among the elderly who had blood samples taken, 1,408 were genotyped for apoE polymorphism; allele frequencies ( $\varepsilon 3: 80.0 \%$; $\varepsilon 4: 13.5 \%$; $\varepsilon 2: 6.5 \%$ ) were within the Hardy-Weinberg equilibrium expectations 31 . The $\varepsilon 3 \varepsilon 3$ genotype was the most commonly observed (63.3\%), followed by $\varepsilon 3 \varepsilon 4$ (22\%), $\varepsilon 2 \varepsilon 3$ (11.4\%), $\varepsilon 4 \varepsilon 4$ (1.8\%), $\varepsilon 2 \varepsilon 4$ (1.4\%) and $\varepsilon 2 \varepsilon 2(0.1 \%)$.

Table 1 shows the baseline characteristics of the study population according to the genotype groups. The average age of the population was 69 years old, wherein $39.4 \%$ represented men, 
Table 1

Characteristics of the participants of the study, according to the apolipoprotein E genotype. Baseline of the Bambui Health and Aging Study.

\begin{tabular}{|c|c|c|c|c|c|}
\hline \multirow[t]{2}{*}{ Variables } & \multirow[t]{2}{*}{ Total } & \multicolumn{3}{|c|}{ ApoE genotype * } & \multirow[t]{2}{*}{$\mathrm{p}$-value ** } \\
\hline & & $\varepsilon 3$ & $\varepsilon 2$ & $\varepsilon 4$ & \\
\hline Age in years [mean (SD)] & $69.0(7.1)$ & $69.1(7.1)$ & $68.4(6.6)$ & $69.0(7.1)$ & 0.457 \\
\hline Gender - male [n (\%)] & 547 (39.4) & $342(38.3)$ & $68(42.0)$ & $137(41.0)$ & 0.539 \\
\hline Skin color - non-white [n (\%)] & $552(39.8)$ & $358(40.1)$ & $66(40.7)$ & $128(38.3)$ & 0.817 \\
\hline Schooling $<4$ years [n (\%)] & 900 (64.9) & $575(64.5)$ & $98(60.9)$ & $227(68.0)$ & 0.276 \\
\hline Current smokers [n (\%)] & $253(18.2)$ & $151(16.9)$ & $33(20.4)$ & $69(20.7)$ & 0.242 \\
\hline HDL [mean (SD)] & $49.0(14.0)$ & $49.1(14.7)$ & $50.7(16.0)$ & $48.2(14.9)$ & 0.202 \\
\hline LDL [mean (SD)] & $155.5(45.4)$ & $155.9(45.2)$ & $140.3(42.0)$ & $161.7(46.1)$ & $<0.001$ \\
\hline Hypertension [n (\%)] & $849(61.3)$ & $556(62.4)$ & $96(59.3)$ & $197(59.2)$ & 0.501 \\
\hline Diabetes [n (\%)] & $195(14.1)$ & $119(13.4)$ & $27(16.7)$ & $49(14.7)$ & 0.498 \\
\hline Angina [n (\%)] & $123(8.9)$ & $83(9.4)$ & $10(6.2)$ & $30(9.0)$ & 0.436 \\
\hline Myocardial infarction [n (\%)] & $69(5.0)$ & $41(4.6)$ & $14(8.6)$ & $14(4.2)$ & 0.073 \\
\hline Stroke [n (\%)] & $50(3.6)$ & $34(3.8)$ & $5(3.1)$ & $11(3.3)$ & 0.849 \\
\hline Mini-mental < 22 [n (\%)] & $279(20.6)$ & $174(20.0)$ & $33(20.4)$ & $72(22.2)$ & 0.718 \\
\hline C-reactive protein (mg/L) [median (P25-P75)] & $3.2(1.4-6.6)$ & $3.3(1.5-6.9)$ & $4.2(1.8-6.8)$ & $2.5(1.3-5.6)$ & $<0.001$ \\
\hline Disable in BADL *** [n (\%)] & $116(8.4)$ & $79(8.9)$ & $14(8.6)$ & $23(6.9)$ & 0.540 \\
\hline Bathing [n (\%)] & $95(6.9)$ & $66(7.4)$ & $10(6.2)$ & $19(5.7)$ & 0.540 \\
\hline Dressing [n (\%)] & $52(3.8)$ & $34(3.8)$ & $7(4.3)$ & $11(3.3)$ & 0.843 \\
\hline Getting in and out of bed [n (\%)] & $21(1.5)$ & $14(1.6)$ & $3(1.9)$ & $4(1.2)$ & 0.835 \\
\hline Feeding [n (\%)] & $18(1.3)$ & $12(1.4)$ & $3(1.9)$ & $3(0.9)$ & 0.666 \\
\hline Disable in IADL ${ }^{\star \star \star}[\mathrm{n}(\%)]$ & $190(13.7)$ & $127(14.3)$ & $23(14.2)$ & $40(12.0)$ & 0.587 \\
\hline Money management [n (\%)] & $86(6.2)$ & $60(6.7)$ & $12(7.4)$ & $14(4.2)$ & 0.210 \\
\hline Housekeeping [n (\%)] & $125(9.0)$ & $87(9.8)$ & $14(8.6)$ & $24(7.2)$ & 0.375 \\
\hline Cooking $[n(\%)]$ & $116(8.4)$ & $78(8.8)$ & $12(7.4)$ & $26(7.8)$ & 0.777 \\
\hline 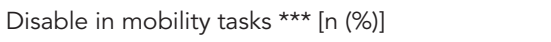 & $352(25.4)$ & $241(27.1)$ & $43(26.5)$ & $68(20.4)$ & 0.056 \\
\hline Walking 3 or 4 blocks [n (\%)] & $100(7.2)$ & $67(7.5)$ & $16(9.9)$ & $17(5.1)$ & 0.132 \\
\hline Climbing steps [n (\%)] & $141(10.2)$ & $98(11.0)$ & $14(8.6)$ & $29(8.7)$ & 0.394 \\
\hline Tilting, squatting and kneeling [n (\%)] & $214(15.4)$ & $147(16.5)$ & $25(15.4)$ & $42(12.6)$ & 0.246 \\
\hline Lifting or carrying $5 \mathrm{~kg}$ of weight [n (\%)] & $178(12.8)$ & $125(14.0)$ & $17(14.5)$ & $36(10.8)$ & 0.207 \\
\hline Walking from a room to another [n (\%)] & $21(1.5)$ & $13(1.5)$ & $3(1.9)$ & $5(1.5)$ & 0.932 \\
\hline Getting up from a chair without assistance [n (\%)] & $74(5.3)$ & $51(5.7)$ & $7(4.3)$ & $16(4.8)$ & 0.674 \\
\hline Walking without assistance [n (\%)] & $74(5.4)$ & $44(4.9)$ & $16(9.9)$ & $15(4.5)$ & 0.027 \\
\hline
\end{tabular}

BADLs: basic activities of daily living; HDL: high-density lipoprotein cholesterol; IADLs: instrumental activities of daily living; LDL: light-density lipoprotein cholesterol.

${ }^{*} \varepsilon 3(\varepsilon 3 \varepsilon 3) ; \varepsilon 2(\varepsilon 2 \varepsilon 2, \varepsilon 2 \varepsilon 3) ; \varepsilon 4(\varepsilon 4 \varepsilon 4, \varepsilon 3 \varepsilon 4) ;$

** $\mathrm{p}$-value from chi-square, variance analysis ou median test;

$\star \star \star$ Disabilities in at least one of the tasks of the group.

$39.8 \%$ represented non-whites, $64.9 \%$ had low education and $18.2 \%$ were smokers. There are also other characteristics shown in Table 1. In this sample, $8.4 \%$ of individuals could not perform at least one BADL-related task on their own. This rate increased to $13.7 \%$ for IADL-related tasks and $25.4 \%$ for mobility-related tasks. The $\varepsilon 4$-carrier group displayed higher LDL-cholesterol levels, lower median CRP and a lower occurrence of elderly who were unable to walk without assistance.

The association between apoE genotypes, as well as the presence of $\varepsilon 4$ allele and functional impairment in BADL, IADL and mobility-related tasks are shown in Tables 2 and 3. Association between $\varepsilon 4$ allele presence and a better performance in mobility-related tasks could be detected when compared to reference genotype $\varepsilon 3 / \varepsilon 3$ 
Table 2

Associations between apolipoprotein E genotypes and disabilities in mobility-related tasks, IADLs e BADLs. Baseline of Bambuí Health and Aging Study.

\begin{tabular}{|c|c|c|c|c|c|c|}
\hline \multirow{3}{*}{$\begin{array}{l}\text { Disabilities/ApoE } \\
\text { genotype * }\end{array}$} & \multicolumn{2}{|c|}{ Disabilities } & OR $(95 \% \mathrm{Cl})$ & OR $(95 \% \mathrm{Cl})$ & OR $(95 \% \mathrm{Cl})$ & OR $(95 \% \mathrm{Cl})$ \\
\hline & \multicolumn{2}{|c|}{ N (\%) } & \multirow[t]{2}{*}{ Not adjusted } & \multirow[t]{2}{*}{ Adjusted by age and gender } & \multirow{2}{*}{$\begin{array}{c}\text { Adjusted by age, } \\
\text { gender, skin color, } \\
\text { schooling and smoking } \\
\text { status }\end{array}$} & \multirow[b]{2}{*}{$\begin{array}{l}\text { Adjusted by age, gender } \\
\text { skin color, schooling, } \\
\text { smoking status, cognitive } \\
\text { impairment, CHD, stroke } \\
\text { hypertension, diabetes, } \\
\text { HDL, LDL, and CRP }\end{array}$} \\
\hline & Yes ** & No & & & & \\
\hline \multicolumn{7}{|l|}{ Mobility } \\
\hline$\varepsilon 2$ & $43(12.2)$ & $119(11.5)$ & $0.97(0.67-1.42)$ & $1.03(0.70-1.52)$ & $1.02(0.69-1.51)$ & $1.07(0.70-1.62)$ \\
\hline$\varepsilon 3$ & $241(68.5)$ & $650(62.9)$ & 1.00 (reference) & 1.00 (reference) & 1.00 (reference) & 1.00 (reference) \\
\hline$\varepsilon 4$ & 68 (19.3) & $265(25.6)$ & $0.69(0.51-0.94)$ & $0.69(0.50-0.94)$ & $0.66(0.48-0.90)$ & $0.66(0.47-0.93)$ \\
\hline \multicolumn{7}{|l|}{ IADLs } \\
\hline$\varepsilon 2$ & $23(12.1)$ & $139(11.6)$ & $1.00(0.62-1.61)$ & $1.07(0.65-1.76)$ & $1.06(0.64-1.75)$ & $1.12(0.64-1.95)$ \\
\hline$\varepsilon 3$ & $127(66.8)$ & 764 (63.9) & 1.00 (reference) & 1.00 (reference) & 1.00 (reference) & 1.00 (reference) \\
\hline$\varepsilon 4$ & $40(21.1)$ & $293(24.5)$ & $0.82(0.56-1.20)$ & $0.80(0.54-1.19)$ & $0.78(0.52-1.16)$ & $0.84(0.53-1.33)$ \\
\hline \multicolumn{7}{|l|}{ BADLs } \\
\hline$\varepsilon 2$ & $14(12.1)$ & $148(11.7)$ & $0.97(0.54-1.76)$ & $1.05(0.58-1.93)$ & $1.03(0.55-1.93)$ & $0.95(0.47-1.91)$ \\
\hline$\varepsilon 3$ & $79(68.1)$ & $812(63.9)$ & 1.00 (reference) & 1.00 (reference) & 1.00 (reference) & 1.00 (reference) \\
\hline$\varepsilon 4$ & $23(19.8)$ & $310(24.4)$ & $0.76(0.47-1.24)$ & $0.76(0.47-1.25)$ & $0.74(0.45-1.21)$ & $0.63(0.35-1.13)$ \\
\hline
\end{tabular}

95\% Cl: 95\% confidence interval; BADLs: basic activities of daily living; CHD: coronary heart disease; CRP: C-reactive protein; HDL: high-density lipoprotein cholesterol; IADLs: instrumental activities of daily living; LDL: light-density lipoprotein cholesterol; OR: odds ratio.

* $\varepsilon 3(\varepsilon 3 \varepsilon 3) ; \varepsilon 2(\varepsilon 2 \varepsilon 2, \varepsilon 2 \varepsilon 3) ; \varepsilon 4(\varepsilon 4 \varepsilon 4, \varepsilon 3 \varepsilon 4)$;

** Disabilities in at least one of the tasks of the group.

Table 3

Association between $\varepsilon 4$ allele and disabilities in mobility-related tasks, IADLs e BADLs. Baseline of the Bambuí Health and Aging Study.

\begin{tabular}{|c|c|c|c|c|c|c|}
\hline \multirow{3}{*}{$\begin{array}{l}\text { Disabilities/\&4 } \\
\text { carriers }\end{array}$} & \multicolumn{2}{|c|}{ Disabilities } & OR $(95 \% \mathrm{Cl})$ & OR $(95 \% \mathrm{Cl})$ & OR $(95 \% \mathrm{Cl})$ & OR $(95 \% \mathrm{Cl})$ \\
\hline & \multicolumn{2}{|c|}{$N(\%)$} & \multirow[t]{2}{*}{ Not adjusted } & \multirow{2}{*}{$\begin{array}{c}\text { Adjusted by age and } \\
\text { gender }\end{array}$} & \multirow{2}{*}{$\begin{array}{l}\text { Adjusted by age, } \\
\text { gender, skin color, } \\
\text { schooling and } \\
\text { smoking status }\end{array}$} & \multirow{2}{*}{$\begin{array}{c}\text { Adjusted by age, } \\
\text { gender, skin color, } \\
\text { schooling, smoking } \\
\text { status, cognitive } \\
\text { impairment, CHD, } \\
\text { stroke, hypertension, } \\
\text { diabetes, HDL, LDL, } \\
\text { and CRP }\end{array}$} \\
\hline & Yes * & No & & & & \\
\hline \multicolumn{7}{|l|}{ Mobility } \\
\hline Non $\varepsilon 4$ carriers & $284(80.7)$ & $769(74.4)$ & 1.00 (reference) & 1.00 (reference) & 1.00 (reference) & 1.00 (reference) \\
\hline$\varepsilon 4$ carriers & $68(19.3)$ & $265(25.6)$ & $0.69(0.52-0.94)$ & $0.68(0.50-0.93)$ & $0.65(0.48-0.89)$ & $0.65(0.47-0.92)$ \\
\hline \multicolumn{7}{|l|}{ IADLs } \\
\hline Non $\varepsilon 4$ carriers & $150(79.0)$ & $903(75.5)$ & 1.00 (reference) & 1.00 (reference) & 1.00 (reference) & 1.00 (reference) \\
\hline$\varepsilon 4$ carriers & $40(21.0)$ & $293(24.5)$ & $0.82(0.57-1.19)$ & $0.79(0.54-1.16)$ & $0.77(0.52-1.14)$ & $0.83(0.53-1.29)$ \\
\hline \multicolumn{7}{|l|}{ BADLs } \\
\hline Non $\varepsilon 4$ carriers & $93(80.2)$ & $960(75.6)$ & 1.00 (reference) & 1.00 (reference) & 1.00 (reference) & 1.00 (reference) \\
\hline$\varepsilon 4$ carriers & $23(19.8)$ & $310(24.4)$ & $0.77(0.48-1.23)$ & $0.76(0.47-1.23)$ & $0.73(0.45-1.20)$ & $0.63(0.35-1.13)$ \\
\hline
\end{tabular}

95\% Cl: 95\% confidence interval; BADLs: basic activities of daily living; CHD: coronary heart disease; CRP: C-reactive protein; HDL: high-density lipoprotein cholesterol; IADLs: instrumental activities of daily living; LDL: light-density lipoprotein cholesterol; OR: odds ratio.

* Disabilities in at least one of the tasks of the group. 
$(\mathrm{OR}=0.66 ; 95 \%$ CI: 0.47-0.93) (Table 2) or when compared to non- $\varepsilon 4$ carriers $(\mathrm{OR}=0.65 ; 95 \% \mathrm{CI}$ : 0.47-0.92) (Table 3), even after a complete adjustment for all confounding factors.

The analysis considering the number of $\varepsilon 4$ alleles showed similar results to those presented in Table 3, but the association between the presence of two alleles $(\varepsilon 4 \varepsilon 4)$ and disability in the mobility-related tasks was not statistically significant (OR $=0.61$; 95\%CI: 0.21-1.76), possibly due to the reduced number of homozygotes in this population (1.8\%) (data not shown in the table).

\section{Discussion}

This research showed a significant association between the presence of $\varepsilon 4$ allele and lower odds of disability in the mobility-related tasks assessed, even after adjustment for confounding factors, in a population of the Brazilian elderly with low-education levels. Given the importance of functional status in healthy aging and the lack of studies addressing this kind of association, the results of the present study provide important information about this issue in an elderly population in Latin America.

The literature has shown inconsistent results about the influence of the apoE genotype in elderly functional performance. A case-control study conducted in a sample of Italian octogenarians and nonagenarians failed to detect an association between the apoE genotype and severe BADL disability, although the frequency of $\varepsilon 4$-carriers was higher among those elderly that were considered "healthy". However, no confounding factor was considered in the analysis of the data 16. A Taiwanese nested case-control study addressing the $\varepsilon 2$ and $\varepsilon 4$ allele presence influence and functional decline in BADL, IADL and mobility among elderly reported similar results. A genotype-dependent variation could not be found for this population when compared with individuals who presented functional decline and age and gender-matched controls. The analysis for this study was adjusted considering confounding factors 15.

Some North-American studies have reported a positive association between the presence of $\varepsilon 4$ allele and disability. The first study to test this association was conducted in a sample of non-demented community-dwelling elderly who were free of stroke, Parkinson disease and depression 20 . It reported the presence of $\varepsilon 4$ allele associated to greater odds of self-reported functional limitation in BADL, even after adjustment for confounding factors (age, gender, schooling and scores in neuropsychological tests). However another study found no significant association between the presence of $\varepsilon 4$ allele and functional decline in BADL, IADL and physical health after four years of follow-up, although the authors reported interaction of the $\varepsilon 4$ allele and female gender 18. An interaction with gender among an elderly population of 627 living in a community was reported over a median follow-up of three years, and male elders carrying $\varepsilon 4$ allele showed a greater risk of disability in BADL and a more rapid gait speed decline than male noncarriers 17. In the Bambuí study, a gender interaction with the apoE genotype and functional performance was not found (data not shown).

Another study, conducted in a group of elderly people from the Netherlands, made use of performance tests and self-reported mobility disability for assessing functional status. For this Dutch research, the presence of $\varepsilon 4$ allele was associated with poor performance in the five chair stand test but not in self-reports 19 .

A sub-sample of 1,805 elderly American participants who took part in the National LongTerm Care Survey (NLTCS) in 1999, showed that disability status is sensitive to apoE polymorphism, however, contrary to previous reports, this study reports that female $\varepsilon 4 \varepsilon 4$ carriers have diminished chances of developing BADL disabilities (OR $=0.19$; 95\%CI: 0.40-0.99). On the other hand, the $\varepsilon 2 \varepsilon 3$ genotype increased the chances of IADL impairments in males $(\mathrm{OR}=2.33$; 95\%CI: 1.28-4.25) 14 , and, heretofore, that was the first study to show a positive effect of $\varepsilon 4$ allele in elderly functional performance. In the Bambuí study, although no association between the apoE genotype and BADL or IADL was detected, $\varepsilon 4$ carriers showed better completion in mobilityrelated tasks.

Many researchers have considered the $\varepsilon 4$ allele to be the ancestral allele, which has been replaced by the $\varepsilon 3$ allele along human evolution. In order to explain this hypothesis, it was postulated that the adverse effects of $\varepsilon 4$ may have been balanced in an earlier time of higher prevalence of infectious diseases by increased host resistance, yet the adverse effects have been amplified because of the increase in longevity 32 . There is, indeed, a greater $\varepsilon 4$ allele frequency in populations where the prevalence of infection and nutritional diseases is still high $33,34,35$. Studies conducted in a Brazilian shantytown located in Fortaleza, the capital city of the state of Ceará (in the Northeast of Brazil), found that early childhood diarrhea and enteric parasitic infections were less frequent in $\varepsilon 4$-carriers, suggesting a protecting effect against parasitic infections 36,37 . The $\varepsilon 4$ allele is considered a "thrifty" genotype, providing advantages in pathogen resistance, particularly 
in situations of malnourishment 38. Considering that, in the past, living conditions in Bambuí were very close to living conditions of pre-industrialized populations, $\varepsilon 4$-carriers may have taken advantage of this condition.

Another potential explanation for the results found in the present study is the fact that the presence of the $\varepsilon 4$ allele leads to greater intestinal absorption and renal reuptake of vitamin $\mathrm{D}$ 39. It has been suggested that higher concentrations of this vitamin may promote physical performance 40,41 , decreasing the risk of mobility limitation 42 . However, vitamin D concentration was not performed in the present study, making it difficult to evaluate this hypothesis.

It is also important to point out that in this same population, the presence of $\varepsilon 4$ allele is associated with lower cognitive performance 43 , but we considered cognitive functioning to be a confounding factor. In addition, it has been shown that the cognitive deficit is more strongly associated with the decline of IADL (which was not associated with apoE genotypes in this study) compared with BADL and mobility ${ }^{18}$, showing that other factors may modulate this association, besides cognitive decline ${ }^{44}$.

The current study has its limitations, due to its cross-sectional design and the possibility of survivorship bias that would decrease the frequency of $\varepsilon 4$-carriers in the sample, since this allele has been associated to mortality in some populations. In Bambuí, however, the apoE genotype did not predict mortality in the first nine years of follow up 11, a fact that minimizes the in- fluence of survivorship bias in the data presented. Another limitation concerns the use of selfreports to assess functional performance, given that a previous study detected the impact of apoE polymorphism in tested mobility performance but not in self-reported mobility limitations 19 . Another point to be considered is the possibility of residual confounding, considering the wide range of mobility determinants (cognitive, psychosocial, physical, environmental, financial and personal life history) 44 , but it was not the aim of this study to explore these determinants. On the other hand, the main advantage of this study is that it concerns a population-based study conducted by a well-trained team that carefully collected all data using standardized protocols and followed strict quality control. It is also the first study to test an association between the apoE genotype and disability in a Latin American elderly population. It is therefore expected that this research will contribute to a better understanding in this field.

Given the above, it can be said, in short, that this study has shown the protective effect against mobility-related disabilities of the $\varepsilon 4$ allele in a population living in a community, even when taking into consideration potential confounding factors. The reasons are not fully understood but may relate to its role as a thrifty gene in a sample exposed to high risk of infectious and nutritional diseases. It is also important to consider genegene and/or gene-environment interactions dealing with apoE and functional performance in the elderly.

\section{Contributors}

R. Z. Megale contributed to the study conception and design, analysis of data, and drafting of manuscript. A. I. Loyola Filho and M. F. Lima-Costa contributed to the study design and critical revision. J. O. A. Firmo contributed to the study design, acquisition of data and critical revision. S. V. Peixoto contributed to the study conception and design, analysis of data, drafting of manuscript and critical revision.

\section{Acknowledgments}

We wish to acknowledge the CNPq (Brazilian National Research Council), for financial support. Josélia O. A. Firmo, Maria Fernanda Lima-Costa and Sérgio V. Peixoto are researchers who receive grants from the CNPq.

\section{References}

1. Mahley RW, Rall Jr. SC. Apolipoprotein E: far more than a lipid transport protein. Annu Rev Genomics Hum Genet 2000; 1:507-37.

2. Wilson PW, Schaefer EJ, Larson MG, Ordovas JM. Apolipoprotein E alleles and risk of coronary disease: a meta-analysis. Arterioscler Thromb Vasc Biol 1996; 16:1250-5.

3. Song Y, Stampfer MJ, Liu S. Meta-analysis: apolipoprotein E genotypes and risk for coronary heart disease. Ann Intern Med 2004; 141:137-47.

4. Eichner JE, Dunn ST, Perveen G, Thompson DM, Stewart KE, Stroehla BC. Apolipoprotein E polymorphism and cardiovascular disease: a HuGE review. Am J Epidemiol 2002; 155:487-95. 
5. McCarron MO, Delong D, Alberts MJ. The apoE genotype as a risk factor for ischemic cerebrovascular disease: a meta-analysis in process citation. Neurology 1999; 53:1308-11.

6. Chouraki V, Seshadri S. Genetics of Alzheimer's disease. Adv Genet 2014; 87:245-94.

7. Lane-Donovan C, Philips GT, Herz J. More than cholesterol transporters: lipoprotein receptors in CNS function and neurodegeneration. Neuron 2014; 83:771-87.

8. Frisoni GB, Louhija J, Geroldi C, Trabucchi M. Longevity and the $\varepsilon 2$ allele of apolipoprotein $\mathrm{E}$ : the Finnish centenarians study. J Gerontol A Biol Sci Med Sci 2001; 56:M75-8.

9. Cauley JA, Eichner JE, Kamboh MI, Ferrell RE, Kuller LH. The apoE allele frequencies in younger (age 42-50) versus older (age 65-90) women. Genet Epidemiol 1993; 10:27-34.

10. Bathum L, Christiansen L, Jeune B, Vaupel J, McGue M, Christensen K, et al. Apolipoprotein e genotypes: relationship to cognitive functioning, cognitive decline, and survival in nonagenarians. J Am Geriatr Soc 2006; 54:654-8.

11. Lima-Costa MF, Peixoto SV, Taufer M, Moriguchi EH. Apolipoprotein e genotype does not predict 9 -year all-cause mortality in brazilian older adults: the Bambui Cohort Study. J Am Geriatr Soc 2008; 56:2366-8.

12. Gerdes LU, Jeune B, Ranberg KA, Nybo H,Vaupel JW. Estimation of apolipoprotein e genotype-specific relative mortality risks from the distribution of genotypes in centenarians and middle-aged men: apolipoprotein e gene is a "frailty gene," not a "longevity gene". Genet Epidemiol 2000; 19:20210.

13. Chistensen K, Johnson TE, Vaupel JW. The quest for genetic determinants of human longevity: challenges and insights. Nat Rev Genet 2006; 7:436-48.

14. Kulminski A, Ukraintseva SV, Arbeev KG, Manton KG, Oshima J, Martin GM, et al. Association between APOE $\varepsilon 2 / \varepsilon 3 / \varepsilon 4$ polymorphism in disability severity in a national long-term care survey sample. Age Aging 2008; 37:288-93.

15. Lan TY, Chang WC, Lan TH, Hurng BS. Apolipoprotein e genotype and risk of developing physical limitations in elderly people. J Am Geriatr Soc 2009; 57:1308-9.

16. Bader G, Zuliani G, Kostner GM, Fellin R. Apolipoprotein E polymorphism is not associated with longevity or disability in a sample of italian octo and nonagenerians. Gerontology 1998; 44:293-9.

17. Verghese J, Holtzer R, Wang C, Katz MJ, Barzilai N, Lipton RB. Role of APOE genotype in gait decline and disability in aging. J Gerontol A Biol Sci Med Sci 2013; 68:1395-401.

18. Blazer DG, Fillenbaum G, Burchett B. The ApoE-E4 allele and the risk of funcional decline in a community sample of African-American and white older adults. J Gerontol A Biol Sci Med Sci 2001; 56:M785-9.

19. Melzer D, Dik MG, van Kamp GJ, Jonker C, Deeg DJ. The apolipoprotein E $\varepsilon 4$ polymorphism is strongly associated with poor mobility performance test results but not self-reported limitation in older people. J Gerontol A Biol Sci Med Sci 2005; 60:1319-23.
20. Albert SM, Gurland B, Maestre G, Jacobs DM, Stern Y, Mayeux R. APOE genotype influences funcional status among elderly without dementia. Am J Genet 1995; 60:583-7.

21. Kulminski AM, Ukraintseva SV, Arbeev KG, Manton KG, Oshima J, Martin GM, et al. Health-protective and adverse effects of the apolipoprotein $\mathrm{E} \varepsilon 2$ allele in older males. J Am Geriatr Soc 2008; 56:478-83.

22. Lima-Costa MF, Firmo JOA, Uchoa E. Cohort profile: the Bambui (Brazil) Cohort Study of Ageing. Int J Epidemiol 2011; 40:862-7.

23. Lima-Costa MF, Firmo JOA, Uchôa E. The Bambuí Cohort Study of Aging: methodology and health profile of participants at baseline. Cad Saúde Pública 2011; 27 Suppl 3:S327-35.

24. Katz S, Ford AB, Moskowitz RW, Jackson BA, Jaffe MW. Studies of illness in the aged. The index of ADL a standardized measure of biological and psychosocial function. JAMA 1963; 185:914-9.

25. Lawton MP, Brody EM. Assessment of older people: self-maintaining and instrumental activities of daily living. Gerontologist 1969; 9:179-86.

26. Alves LC, Leite IC, Machado CJ. Conceituando e mensurando a incapacidade funcional da população idosa: uma revisão da literatura. Ciênc Saúde Coletiva 2008; 13:1199-207.

27. Hixson JE,Vernier DT. Restriction isotyping of human apolipoprotein $\mathrm{E}$ by gene amplification and cleavage with HhaI. J Lipid Res 1990; 31:545-8.

28. Castro-Costa E, Fuzikawa C, Uchoa E, Firmo JO, Lima-Costa MF. Norms for the mini-mental state examination: adjustment of the cut-off point in population-based studies (evidences from the Bambuí health aging study). Arq Neuropsiquiatr 2008; 66:524-8.

29. Plan and operation of the Third National Health and Nutrition Examination Survey, 1988-94. Series 1: programs and collection procedures. Vital Health Stat 1 1994; 32:1-407.

30. Rose G. The diagnosis of ischaemic heart pain and intermittent claudication in field surveys. Bull World Health Organ 1962; 27:645-8.

31. Fuzikawa AK, Peixoto SV, Taufer M, Moriguchi EH, Lima-Costa MF. Apolipoprotein E polymorphism distribution in an elderly Brazilian population: the Bambuí Health and Aging Study. Braz J Med Biol Res 2007; 40:1429-34.

32. Finch CE, Morgan TE. Systemic inflammation, infection, ApoE alleles, and Alzheimer disease: a position paper. Curr Alzheimer Res 2007; 4:185-9.

33. Sepehrnia B, Kamboh MI, Adams-Campbell LL, Nwankwo M, Ferrell RE. Genetic studies of human apolipoproteins. VII. Population distributions of polymorphisms of apolipoproteins A-I, A-II, A-IV, C-II, E and H in Nigeria. Am J Hum Genet 1988; 43:847-53.

34. Hallman DM, Boerwinkle E, Saha N, Sandholzer C, Menzel HJ, Csazar A, et al. The apolipoprotein E polymorphism: a comparison of allele frequencies and effects in nine populations. Am J Hum Genet 1991; 49:338-49.

35. Sandholzer C, Delport R, Vermaak H, Utermann G. High frequency of the apo 4 allele in Khoi San from South Africa. Hum Genet 1995; 95:46-8. 
36. Oriá RB, Patrick PD, Blackman JA, Lima AA, Guerrant RL. Role of apolipoprotein E4 in protecting children against early childhood diarrhea outcomes and implications for later development. Med Hypotheses 2007; 68:1099-107.

37. Oriá RB, Patrick PD, Oriá MO, Lorntz B, Thompson MR, Azevedo OG, et al. ApoE polymorphisms and diarrheal outcomes in Brazilian shanty town children. Braz J Med Biol Res 2010; 43:249-56.

38. Jofre-Monseny L, Minihane AM, Rimbach G. Impact of apoE genotype on oxidative stress, inflammation and disease risk. Mol Nutr Food Res 2008; 52:131-45.

39. Huebbe P, Nebel A, Siegert S, Moehring J, BoeschSaadatmandi C, Most E, et al. APOE $\varepsilon 4$ is associated with higher vitamin D levels in targeted replacement mice and humans. FASEB J 2011; 25:3262-70.

40. Houston DK, Cesari M, Ferrucci L, Cherubini A, Maggio D, Bartali B, et al. Association between vitamin D status and physical performance: the InCHIANTI study. J Gerontol A Biol Sci Med Sci 2007; 62:440-6.

\section{Resumo}

Inúmeros estudos têm associado o alelo $\varepsilon 4$ da apolipoproteína E (apoE) com pior condição de saúde, mas poucos avaliaram a existência de variações genótipodependentes no desempenho funcional. Entre os participantes da coorte de Bambuí, Minas Gerais, Brasil, 1.408 idosos foram submetidos à genotipagem da apoE. A funcionalidade foi avaliada por questionário, sendo os indivíduos classificados em dependentes para atividades básicas da vida diária (ABVDs), atividades instrumentais da vida diária (AIVDs) e mobilidade. A associação entre o genótipo da apoE e o estado funcional foi avaliada pela regressão logística, considerando variáveis de confusão. A presença do alelo 4 foi associada a uma menor chance de déficit na mobilidade $(O R=0,65$; IC95\%: 0,47-0,92), na análise ajustada. Não houve diferenças significativas em relação à presença de incapacidades em ABVDs e AIVDs. Os motivos não estão completamente compreendidos, mas podem envolver o seu papel como um "thrifty gene" em uma amostra exposta a um risco elevado de doenças infecciosas e nutricionais no passado.

Apolipoproteína E4; Pessoas com Deficiência; Idoso
41. Zamboni M, Zoico E, Tosoni P, Zivelonghi A, Bortolani A, Maggi S, et al. Relation between vitamin $\mathrm{D}$, physical performance, and disability in elderly persons. J Gerontol A Med Sci 2002; 57:M7-M11.

42. Houston DK, Neiberg RH, Tooze JA, Hausman DB, Johnson MA, Cauley JA, et al. Low 25-hydroxyvitamin D predicts the onset of mobility limitation and disability in community-dwelling older adults: the Health ABC Study. J Gerontol A Biol Sci Med Sci 2013; 68:181-7.

43. Quintino-Santos SR, Lima-Costa MF, Uchoa E, Firmo JOA, Moriguchi EH, Castro-Costa E. Homozygosity for the APOE E4 allele is solely associated with lower cognitive performance in Brazilian community-dwelling older adults - The Bambuí Study. Rev Bras Psiquiatr 2012; 34:440-5.

44. Webber SC, Porter MM, Menec VH. Mobility in older adults: a comprehensive framework. Gerontologist 2010; 50:443-50.

\section{Resumen}

Innumerables estudios han asociado el alelo $\varepsilon 4$ de la apolipoproteína E (apoE) con una peor condición de salud, pero pocos evaluaron la existencia de variaciones genotipo-dependientes en el desempeño funcional. Entre los participantes de la cohorte de Bambuí, Minas Gerais, Brasil, 1.408 ancianos fueron sometidos a una determinación del genotipo de la apoE. La funcionalidad fue evaluada por cuestionario, siendo los individuos clasificados en: dependientes para actividades básicas de la vida diaria (ABVDs), actividades instrumentales de la vida diaria (AIVDs) y movilidad. La asociación entre el genotipo de la apoE y el estado funcional fue evaluada por regresión logística, considerando variables de confusión. La presencia del alelo $\varepsilon 4$ fue asociada a una menor probabilidad de déficit en la movilidad $(O R=0,65$; IC95\%: 0,47-0,92) en el análisis ajustado. No hubo diferencias significativas en relación con la presencia de incapacidades en ABVDs y AIVDs. Los motivos no están completamente claros, pero pueden están involucrados por su papel como un "thrifty gene" en una muestra expuesta a un riesgo elevado de enfermedades infecciosas y nutricionales en el pasado.

Apolipoproteína E4; Personas con Discapacidad; Anciano
Submitted on 19/May/2015

Final version resubmitted on 17/Jul/2015

Approved on 27/Aug/2015 